\title{
Development of the Method for Estimating Cardiac Vagal Activity in Real-Time during Body Motion and Generation of the Interactive CG
}

\author{
Kiyoshi Kotani Non-member (The University of Tokyo, kotani@k.u-tokyo.ac.jp) \\ Fumiaki Iida Non-member (The University of Tokyo, fiida@nanolab.t.u-tokyo.ac.jp) \\ Tomohiro Akagawa Non-member (The University of Tokyo, qq66301@iii.u-tokyo.ac.jp) \\ Takeshi Saitoh Non-member (The University of Tokyo, tsaitoh@iis.u-tokyo.ac.jp) \\ Yasuhiko Jimbo Member (The University of Tokyo, jimbo@k.u-tokyo.ac.jp) \\ Yoichiro Kawaguchi Non-member (The University of Tokyo, yoichiro@iii.u-tokyo.ac.jp) \\ Kiyoshi Takamasu Non-member (The University of Tokyo, takamasu@pe.t.u-tokyo.ac.jp)
}

Keywords: respiratory sinus arrhythmia, vagal activity, interactive CG, growth model

We evaluated errors in the amplitude of RSA under the condition of body motion and proposed a method for reducing them. We applied the proposed method for the purpose of real-time CG interaction and it was tested whether the proposed method can extract the amplitude of RSA in realtime.

Experiments were performed by seven healthy subjects under the condition of (a) sitting rest, (b) keyboard typing, and (c) mental arithmetic with answering by touch panel of $300 \times 300 \mathrm{~mm}$. Electric-cardiogram was sampled at the frequency of $1 \mathrm{kHz}$, while air-flow meter, elastic chest band, and thermistor were sampled at the frequency of $100 \mathrm{~Hz}$. The amplitude of RSA by these sensors were calculated by using three methods of interpolation (i.e. Derivative of cubic spline interpolation, Berger's interpolation method, and instantaneous heart rate method). In each result, the correlation coefficient with the amplitude of RSA by air-flow meter using DCSI method was calculated (Table 1-3).

It was found that elastic chest band is suitable under the quiet condition, while thermistor is suitable under the condition of body motion. It was also found that Berger's interpolation method was the best for detecting instantaneous heartbeat intervals in real-time signal processing.

Furthermore, we proposed an error reduction algorithm. The data of elastic chest band was used if the time lag between the thermistor and elastic chest band was within $300 \mathrm{~ms}$, while that of themistor was used if the time lag was in 300-1000 ms. The proposed method was applied for interactive CG (Computer Graphics) system that reflected the amplitude of RSA estimated in real-time (Fig.1). It was confirmed that the interactive CG reflected RSA amplitude in real-time even under the condition of body motion.
Table 1. Results of Exp. (a). ${ }^{\ddagger} P<0.01$ from the IHR method. ${ }^{*} P<0.01$ from thermistor

\begin{tabular}{cccc}
\hline & DCSI $^{\ddagger}$ & Berger & IHR \\
\hline Thermistor & $0.952 \pm 0.019$ & $0.906 \pm 0.048$ & $0.807 \pm 0.170$ \\
Belt & & & \\
\hline
\end{tabular}

Table 2. Results of Exp. (b). ${ }^{\ddagger} P<0.01$ from the IHR method

\begin{tabular}{cccc}
\hline & DCSI $^{\mp}$ & Berger $^{\mp}$ & IHR \\
\hline Thermistor & $0.940 \pm 0.070$ & $0.932 \pm 0.056$ & $0.851 \pm 0.083$ \\
Belt & $0.986 \pm 0.012$ & $0.948 \pm 0.021$ & $0.866 \pm 0.360$
\end{tabular}

Table 3. Results of Exp. (c). ${ }^{\ddagger} P<0.01$ from the IHR method

\begin{tabular}{cccc}
\hline & DCSI $^{\ddagger}$ & Berger $^{\ddagger}$ & IHR \\
\hline Thermistor & $0.985 \pm 0.007$ & $0.960 \pm 0.197$ & $0.898 \pm 0.050$ \\
Belt & $0.984 \pm 0.011$ & $0.954 \pm 0.022$ & $0.887 \pm 0.047$
\end{tabular}

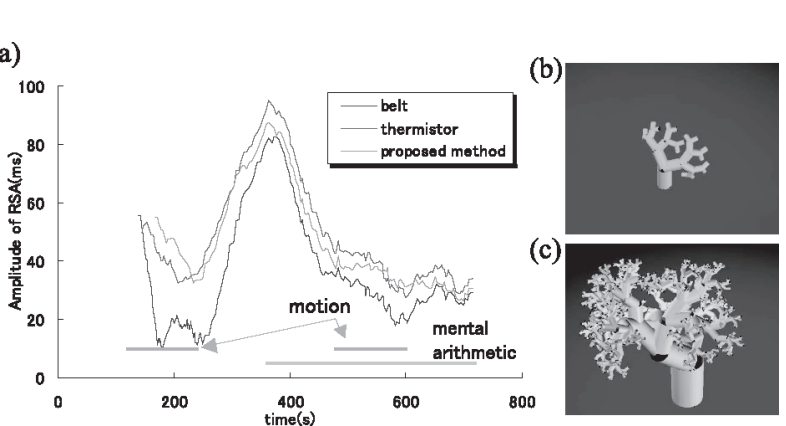

Fig. 1. Result of the interactive CG experiment. (a) the amplitude of RSA by belt, thermistor, and the proposed method. (b) $300 \mathrm{~s}$, (c) $700 \mathrm{~s}$ snapshots of CG that reflected the amplitude of RSA 


\title{
体動の影響下におけるリアルタイム副交感神経活動推定法の 開発とインタラクティブCGの生成
}

$\begin{array}{llllll}\text { 非会員 } & \text { 小谷 } & \text { 潔* } & \text { 非会員 } & \text { 飯田 } & \text { 文明** } \\ \text { 非会員 } & \text { 赤川 } & \text { 智洋*** } & \text { 非会員 } & \text { 斉藤 } & \text { 毅**** } \\ \text { 正 員 神保 } & \text { 泰彦* } & \text { 非会員 } & \text { 河口 } & \text { 洋一郎*** } \\ \text { 正 員 高增 } & \text { 潔**** } & & & \end{array}$

\begin{abstract}
Development of the Method for Estimating Cardiac Vagal Activity in Real-Time during Body Motion and Generation of the Interactive CG

Kiyoshi Kotani*, Non-member, Fumiaki Iida**, Non-member, Tomohiro Akagawa***, Non-member, Takeshi Saitoh ${ }^{* * *}$, Non-member, Yasuhiko Jimbo*, Member, Yoichiro Kawaguchi***, Non-member, Kiyoshi Takamasu****, Member
\end{abstract}

Autonomic nervous system is important to maintain homeostasis, and respiratory sinus arrhythmia (RSA) is known as a selective index of cardiac vagal activity. In this paper, we evaluated errors in the amplitude of RSA under the condition of body motion (keyboard typing and mental arithmetic with touching panel) and proposed a method for reducing them. It was found that elastic chest band is suitable under the quiet condition, while thermistor is suitable under the condition of body motion. It was also found that Berger's interpolation method was the best for detecting instantaneous heartbeat intervals in real-time signal processing. Furthermore, we proposed a error reduction algorithm by mixing the data of thermistor and elastic chest band, and applied it for interactive CG (Computer Graphics) system that reflected the amplitude of RSA estimated in real-time.

キーワード：呼吸性洞性不整脈, 副交感神経活動, インタラクティブ CG, グロースモデル

Keywords: respiratory sinus arrhythmia, vagal activity, interactive CG, growth model

* 東京大学大学院 新領域創成科学研究科

于 277-8561 千葉県柏市柏の葉 5-1-5

Graduate School of Frontier Science, The University of Tokyo

5-1-5, Kashiwanoha, Kashiwa-shi, Chiba 277-8561

** 東京大学 工学部

于 113-8656 東京都文京区本郷 7-3-1

Depertment of Engeneering, The University of Tokyo

7-3-1, Hongo, Bunkyo-ku, Tokyo 113-8656

*** 東京大学大学院 情報学環

T 113-0033 東京都文京区本郷 7-3-1

Graduate School of Interdisciplinary Information Studies, The University of Tokyo

7-3-1, Hongo, Bunkyo-ku, Tokyo 113-0033

**** 東京大学大学院 工学系研究科

T 113-8656 東京都文京区本郷 7-3-1

Graduate School of Engeneering, The University of Tokyo

7-3-1, Hongo, Bunkyo-ku, Tokyo 113-8656

\section{1. はじめに}

自律神経は交感神経と副交感神経の拮抗作用によって各 臟器を支配し，ホメオスタシス (恒常性) の維持に重要な 役割を担っている(1)。そのため, 自律神経活動を知ること は臨床医学研究の他にも, 作業時に㧍ける支援や, 生活環 境下においてのリラクゼーションなどのインタフェースの 最適化に有用であると考えられる。自律神経活動の計測に 関して,筋交感神経についてはタングステンの微小電極に よって侵襲的に計測できることが知られているが(2), 現状 では実生活環境下での計測が可能なほど簡便ではない。さ らに副交感神経に関しては直接計測することはできず，現 段階では推定するしかないといえる。

副交感神経活動の指標としては心拍変動の呼吸性の変動 成分 (RSA：Respiratory Sinus Arrhythmia) の振幅が知 られており (3)(4), 周波数解析を用いて RSA を抽出する手 法 ${ }^{(5)}$ は臨床医学研究 ${ }^{(6)}$ はもとより作業者における快適性 
や集中度の指標として用いられている(7)。そのため, 実際 の作業や生活の現場において，リアルタイムに副交感神経 活動を推定し, 適切に作業や映像などの外部環境を制御す ることが期待されている。

RSA による副交感神経活動推定法については，我々は呼 吸位相領域で心拍変動を解析し, 長い呼吸などの不適当な データを一呼吸ごとに取捨してから RSA の振幅を算出す ることで従来の周波数解析に比べてより高精度に RSAの 振幅を抽出できる手法を提案してきた ${ }^{(8)}$ (10)。さらに提案 手法を拡張してリアルタイムで RSA の振幅を抽出し評価 する手法を開発した ${ }^{(11)}$ 。しかし，実生活環境においてリア ルタイム処理を実現するためには，体動の影響を含めた誤 差要因を考慮する必要がある。

一方で，外部環境の制御に関しては，リアルタイムに測 定された RSA の情報を受け取り，自律神経に影響を与える ような環境要因を適切に制御するシステムを構築する必要 がある。自律神経に影響を与える要因としては様々なもの が考えられるが，その中で本研究では CGによる映像刺激 に着目する。映像刺激は日常生活に密接に関係があり，さ らに自律神経活動に与える影響について研究がなされてい る(12)(13)。

以上から, 本研究においては, リアルタイムで RSA の 振幅を抽出する手法について，机上作業程度の動きのある 状況で実験を行い，体動の影響を低減させる計測手法およ び信号処理手法を開発する。さらに抽出結果を用いた外部 環境制御のひとつとして，外部の PCにRSA の振幅をリ アルタイムで送信し，投影している CGを連動して動かす ことを目的とする。

\section{2. 体動による RSA 振幅の抽出誤差評価実験}

$\langle\mathbf{2} \cdot \mathbf{1}\rangle$ 誤差要因 文献 (11) において提案されている 信号処理アルゴリズムを図 1 に示す。胸部に巻いた伸縮性 のベルト (呼吸ピックアップベルト)によって吸気の開始時 と終了時における瞬時 RRI の差を算出している。このアル ゴリズムにおいて誤差要因として挙げられるのは，体動に よる呼吸計測の誤差と補間法による䛊差である。しかしな がら呼吸計測の誤差が補間法の誤差を介して最終的な RSA 振幅の抽出誤差となるため, この 2 つの誤差要因は独立で はなく連動するものといえる。以下に本研究で用いる計測 手法と補間法についてそれぞれ述べる。

図 2 に流量計 (TV-112T, 日本光電), 呼吸ピックアップ ベルト (TR-753T, 日本光電), サーミスタ (TR-761T, 日 本光電) による呼吸信号の例を示す。呼吸ピックアップベ ルトは呼吸による胸径の変化を, サーミス夕は呼吸の気流 による鼻部の温度変化を抽出する装置である。吸気の開始 時と終了時を同定するにあたり，流量計は 0 をマイナス側 に離れる点とプラス側に横切る点の時刻を算出する。これ らに対応するベルトの点は極大值, 極小值であり, サーミ スタでは 2 回微分の極大值，極小值であるため，以下の実 験ではこれらの生起時刻を同定する。これらの他に, 予備

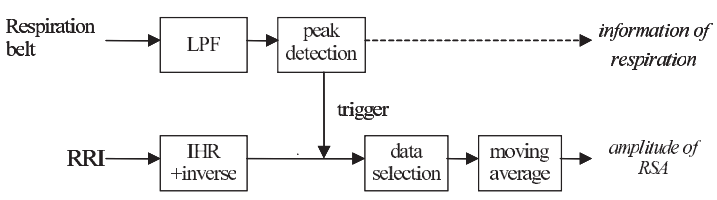

Fig. 1. Signal processing argorithm for the realtime extraction of the amplitude of RSA.

(a)
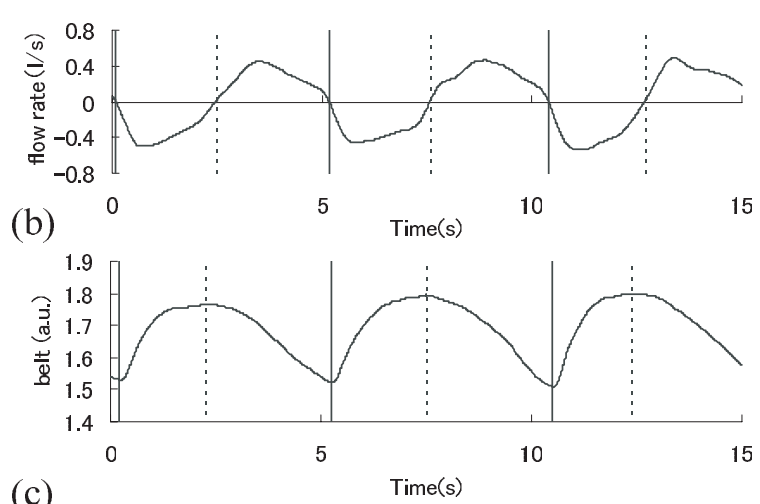

(c)

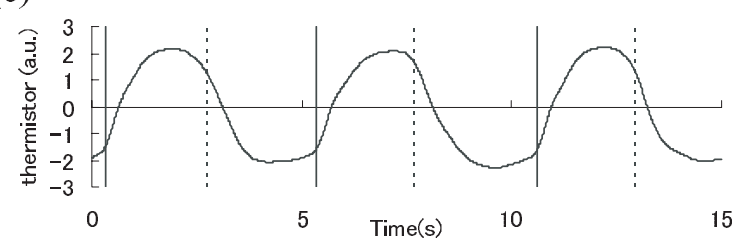

Fig. 2. Waveforms of the (a) air-flow meter, (b) respiration belt, and (c) thermistor in the normal respiration. Solid lines indicate the start points of inspiration and dotted lines indicate the end points of inspiration.

実験として胸部インピーダンスと呼吸音の計測を行ったが, $\mathrm{S} / \mathrm{N}$ 比が悪く, また体動による誤差が大きかったため, 今 回の実験では用いない事とした。

次に, 補間法について述べる。文献 (11) のアルゴリズム を用いるためには, 吸気の開始点・終了点での瞬時 RRI を時間遅れなく得る必要があるため, 図 $3(\mathrm{a})$ のような IPFM(Integral Pulse Frequency Modulator) モデルに基 ついた補間を行う必要がある(14)(15)。IPFM モデルは洞結 節のモデルであり, 積分発火型の構造をしている。このモ デルにおいて $t_{k}(k=0,1,2, \ldots, n)$ を心拍動の生起時刻と した時に

$$
\int_{t_{0}}^{t_{k}} m(t) d t=k \ldots \ldots \ldots \ldots \ldots \ldots \ldots \ldots \ldots \ldots
$$

で表される $m(t)$ が瞬時心拍数となる。呼吸位相領域での解 析で必要とされているのは瞬時 RRI であるため, 逆数であ る $1 / m(t)$ を用いる。IPFM モデルを満たす補間法として, 有名なものに DCSI(Derivative of Cubic Spline Interpolation) 法がある ${ }^{(15)}$ 。DCSI 法は $\left(t_{k}, k\right)$ の点列を 3 次スプ ライン補間することにより， $m(t)$ を求める手法である。し かしながら, DCSI 法はリアルタイムで行うには計算量が 
(a)

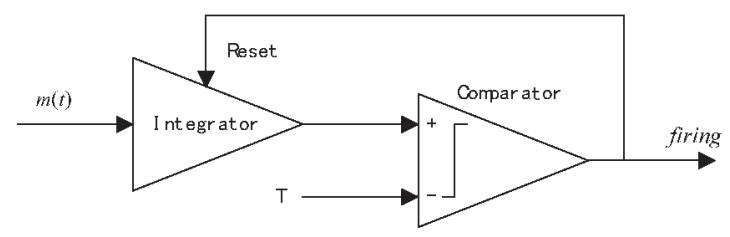

(b)

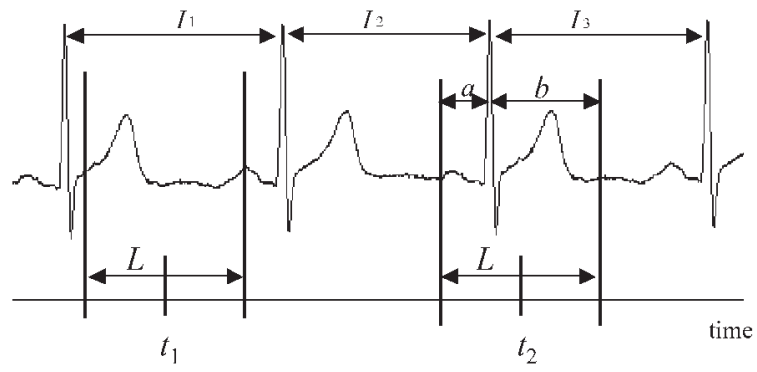

Fig. 3. (a) Block diagram of the IPFM model.

(b)Berger's method for interpolation of the RRI.

多く，また端点条件があるために前後にマージンが必要と なってしまう。さらに，リアルタイムでの解析では後から デー夕を参照する場合と異なり， R 波の誤認識や期外収縮 などを完全になくす事はできないが，その場合に誤った点 の影響が前後のデータにまで及んでしまう。

そこで，DCSI 法に替わる方法として，文献(11)では IHR(Instantaneous Heart Rate) 法を用いている。この手 法は時刻 $t$ における瞬時 RRI を，その前後の $\mathrm{R}$ 波の間隔 とするものであり，(1) 式に扮いて $\left(t_{k}, k\right)$ を直線補間して 得られる $1 / m(t)$ に等しい。IHR 法は簡便であるが，拍動 の前後で值が不連続となるため, 誤差が大きくなってしま うと考えられる。

一方で，IPFM モデルを満たし，かつ連続な補間手法と して, Berger 法がある ${ }^{(16)}$ 。Berger 法は点の前後に幅 $L$ の 局所空を設け，図 3(b) の時刻 $t_{1}$ のように，空の中に $\mathrm{R}$ 波 がなければ $n_{i}=L / I_{1}$, 時刻 $t_{2}$ のように，空の中に $\mathrm{R}$ 波が ある場合は $n_{i}=a / I_{2}+b / I_{3}$ として, 瞬時 RRI $L / n_{i}$ で求めるものである。局所空の幅 $L$ には従来の Berger 法 ではサンプリング間隔が用いられているが，今回のアルゴ リズムにおいては等時間隔の補間ではないために局所空は $500 \mathrm{~ms}$ (前後 $250 \mathrm{~ms}$ ずつ) と設定した。

$\langle 2 \cdot 2\rangle$ 実験条件 健常な男子大学院生 7 名を被験者 として作業下での心拍・呼吸計測を行った。呼吸センサに は流量計，呼吸ピックアップベルト，サーミスタを用いた。 尚，流量計は原理上精度が最も高いと予想されるが，拘束 の強さから実生活環境下での計測には向かないため今回は 精度比較の基準とし, 流量計から呼吸の開始時, 終了時が 同定できない呼吸は解析に用いないこととした。また，サー ミス夕は一般的には鼻に装着するが，本章の実験では口呼 吸によって流量計の值を得る必要があるため, 口に装着し た。サンプリング周波数は, 心電計 $(\mathrm{AC}-601 \mathrm{G}$, 日本光電) は $1 \mathrm{kHz}$ ，呼吸計測は全て $100 \mathrm{~Hz}$ で行った。実験には安
静座位と，体幹が大きく動かない程度の作業 2 つをそれぞ れ $180 \mathrm{~s}$ 課した。実験の内容は以下の (a)-(c) のとおりで ある。

(a) 安静座位

(b) キーボードタイピング：座位でディスプレイに提示 された英文記事をタイプする。

(c) 動作を伴う暗算課題：座位でディスプレイに提示さ れた 2 桁の整数の和を机上に広さ $300 \mathrm{~mm} \times 300 \mathrm{~mm}$ に 配置された数字のパネルに左手で触れることで回答する。 回答すると次の課題が提示される。暗算は文献 (11) と同 様のものを課し，一問当たりの時間制限はなく，180 s の 間暗算を続けるようにした。

$\langle\mathbf{2} \cdot 3\rangle$ 実験結果 各実験について, サーミス夕, 呼吸 ピックアップベルトによる, 吸気の開始点・終了点それぞれ の時間誤差（流量計基準）の絶対值の平均を算出し, サー ミスタと呼吸ピックアップベルトの結果間で paired t-test を行った (図 4)。実験 (a) における吸気の開始点・終了点で はサーミスタよりも呼吸ピックアップベルトの方が時間誤 差が小さく，統計的有意差が見られた（それぞれ $P<0.01$ と $P<0.05)$ 。また, 実験 $(\mathrm{b})$ の吸気の開始点も統計的有 意差は得られなかったものの呼吸ピックアップベルトの方 が誤差が小さかった。一方で実験 (b) の吸気の終了点と実 験 (c) では両者の誤差はほほ等しかった。

次に RSA の振幅について，各センサ並びに各 RRI 補 間手法を用いた結果について, 流量計による呼吸データに DCSI 法を用いて抽出した RSA の振幅を基準值として，基 準值との相関係数を求めた。結果について 2 元配置分散分 析を行い, さらに 3 種類の補間手法をテューキーの多重比 較によって比較した。実験 (a)-(c) の結果をそれぞれ表 1-3 に示す。安静時の実験 (a) においては, サーミスタよりも 呼吸ピックアップベルトの方が精度が高く $(P<0.05)$, さ らに DCSI 法は IHR 法よりも精度が高かった $(P<0.01)$ 。 また実験 (b),(c) ではともに, DCSI 法は IHR 法よりも， Berger 法は IHR 法よりも精度が高かった $(P<0.01)$ 。こ れらの結果から, リアルタイム RSA 抽出においては補間 法は IHR 法よりも Berger 法の方が基準值との相関が高く, 誤差の少ない補間が行われる事が示された。

また, 各実験の作業結果の平均值と標準偏差は以下の通 りであった。キーボードタイピング作業の結果, $180 \mathrm{~s}$ 間に タイピングした文字数は $327 \pm 136$ 文字であった。また, 暗算の結果， $180 \mathrm{~s}$ 間の回答数は $53 \pm 17$ 問，正答率は 94 $\pm 3.6 \%$ であった。

$\langle 2 \cdot 4\rangle$ 考 察 呼吸計測に関して, 実験 $(\mathrm{a})$ の吸気 の開始点・終了点と実験 (b) の吸気の開始点においては呼 吸ピックアップベルトよりもサーミスタの方が誤差が大き かった。その原因はサーミス夕の計測原理によるものと考 えられる。サーミスタは呼吸による温度変化を計測してい るため, 呼気の終了時近辺で測定值が原点に回帰する傾向 がある。そのため, 吸気の開始点を抽出するためには 2 回微 分の極值を抽出する必要がある。2 回微分波形が図 5(a)の 
(a)

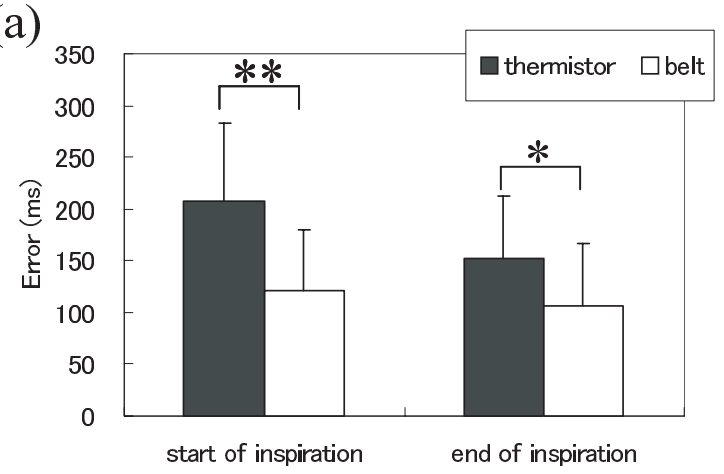

(b)

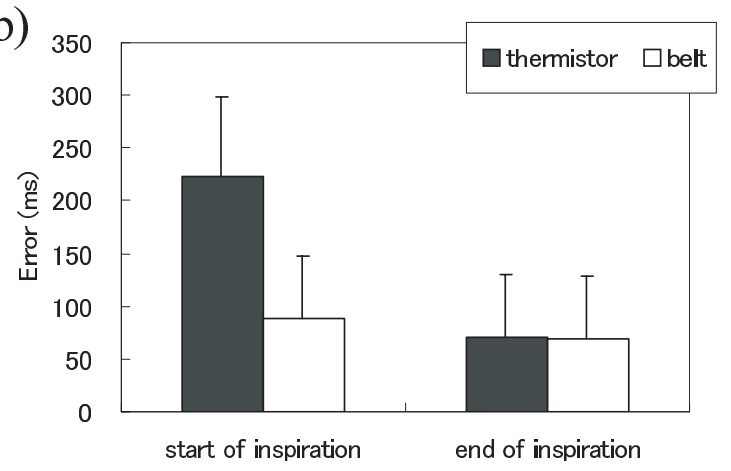

(c)

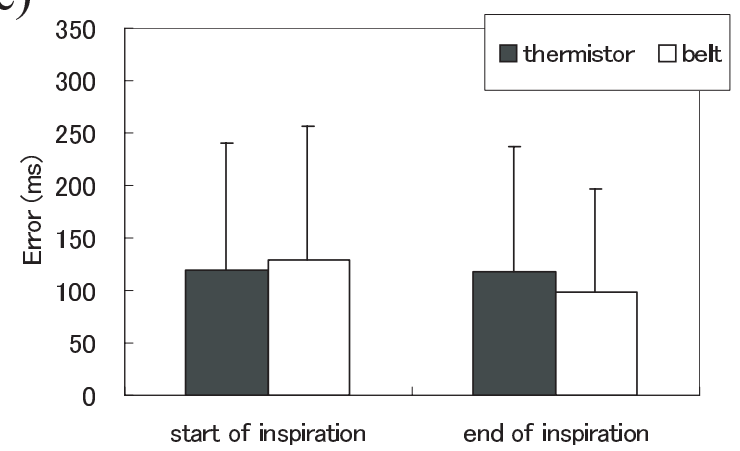

Fig. 4. Errors in the detection of start points and end points of inspiration. (a)-(c) are the results of Exp.(a)-(c), respectively. ${ }^{*}$ indicates $P<0.05$ and ** indicates $P<0.01$.

ような単峰性であれば精度良く抽出可能であるが，図 5(b) のように 2 回微分の波形がきれいな単峰性のピークを持た ない場合などに抽出誤差が生じてしまう。

また，RSA 振幅の抽出誤差についても呼吸誤差と同様 に，実験 (a) に扔いて呼吸ピックアップベルトを用いた方 が高精度であった。実験 (b),(c) においては両者の誤差はほ ほ同程度であったが，実際のデスクワークに打いては，実 験 (b),(c) で課した手の動きとともに体幹の動きも加わる ため, 呼吸ピックアップベルトの精度がより悪化すると考 えられる。そのため，サーミス夕を併用することで，呼吸 計測に㧍ける誤差の低減を図る必要がある。

補間法に関しては，全ての実験において，IHR 法よりも Berger 法の方が基準值との相関係数が高い值が得られた。 これは, Berger 法が, 基準值である流量計による呼吸デー
Table 1. Correlation coefficients of experiment (a). $¥$ indicates statistically significant difference from the interpolation of IHR method $(P<0.01) .{ }^{*}$ indicates statistically significant difference from thermistor $(P<0.01)$

\begin{tabular}{cccc}
\hline & DCSI $^{\ddagger}$ & Berger & IHR \\
\hline Thermistor & $0.952 \pm 0.019$ & $0.906 \pm 0.048$ & $0.807 \pm 0.170$ \\
Belt $^{*}$ & $0.970 \pm 0.030$ & $0.955 \pm 0.013$ & $0.921 \pm 0.033$ \\
\hline
\end{tabular}

Table 2. Correlation coefficients of experiment (b). $\ddagger$ indicates statistically significant difference from the interpolation of IHR method $(P<0.01)$.

\begin{tabular}{cccc}
\hline & DCSI $^{\ddagger}$ & Berger $^{\ddagger}$ & IHR \\
\hline Thermistor & $0.940 \pm 0.070$ & $0.932 \pm 0.056$ & $0.851 \pm 0.083$ \\
Belt & $0.986 \pm 0.012$ & $0.948 \pm 0.021$ & $0.866 \pm 0.360$ \\
\hline
\end{tabular}

Table 3. Correlation coefficients of experiment (c). $¥$ indicates statistically significant difference from the interpolation of IHR method $(P<0.01)$.

\begin{tabular}{cccc}
\hline & DCSI $^{\ddagger}$ & Berger $^{\ddagger}$ & IHR \\
\hline Thermistor & $0.985 \pm 0.007$ & $0.960 \pm 0.197$ & $0.898 \pm 0.050$ \\
Belt & $0.984 \pm 0.011$ & $0.954 \pm 0.022$ & $0.887 \pm 0.047$ \\
\hline
\end{tabular}

(a)

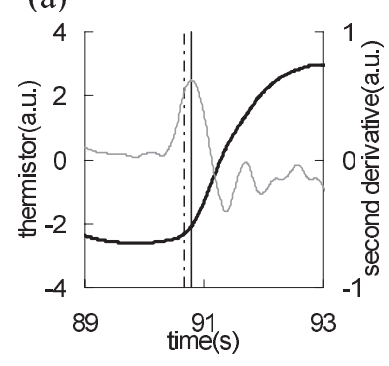

(b)

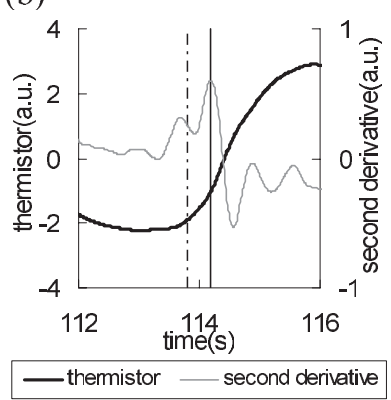

Fig. 5. Two types of waveforms of the thermistor and its second derivative around the start point of inspiration. Vertical solid line indicates the detected start point of inspiration by thermistor, while dashed-dotted line indicates that by air-flow meter.

夕にDCSI 法を用いて解析した結果への追随性が高いこと を示している。

これらの結果から，実生活環境下でのリアルタイム計測 には, 安静時には呼吸ピックアップベルトによる呼吸計測, 体動がある場合にはサーミス夕戦独もしくは呼吸ピックアッ プベルトとの併用が望ましいといえる。さらに Berger 法 を用いた瞬時 RRI 抽出を行うことで高精度な RSA 振幅の 抽出が可能である。

3. 高精度リアルタイム RSA 抽出手法を用いたイ ンタラクティブ CG の生成

〈3・1〉 実験条件 これまでの実験結果を考慮し, 体動 のある状況下での RSA 振幅のリアルタイム抽出手法を構 築して，その值によって CG がインタラクティブに反応す るシステムを作成した。信号処理アルゴリズムは図 6 のと 


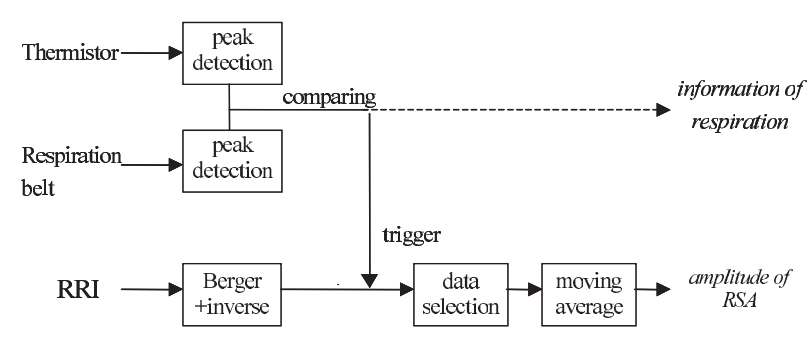

Fig. 6. Proposed method for real-time RSA extraction that is adoptive under the condition of body motion of the subject.

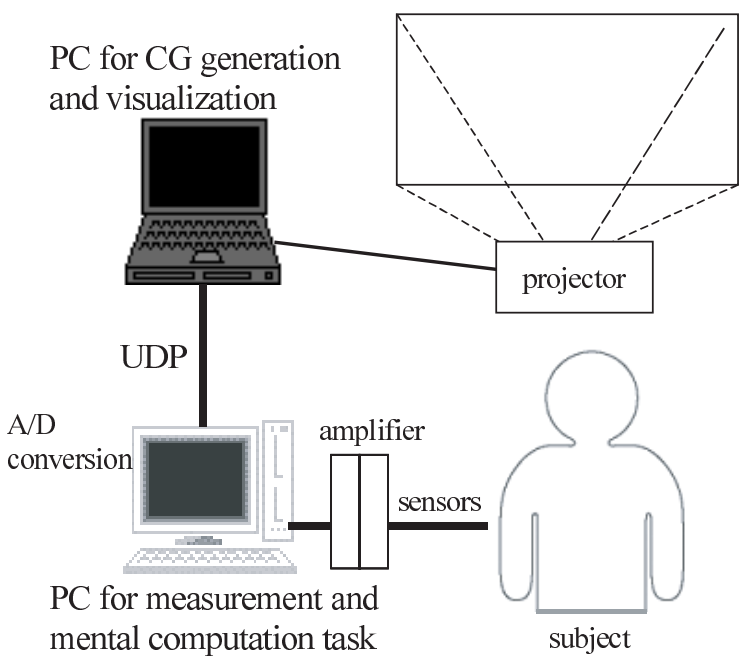

Fig. 7. Configration of the experiment for the realtime RSA extraction with interactive $\mathrm{CG}$

おりで，呼吸情報として呼吸ピックアップベルトとサーミ ス夕を取得し，瞬時 RRIの補間には Berger 法を用いる。 サーミスタから安定した呼吸情報をリアルタイムで取得す るため, 2 回微分の極大值もしくは極小值が $1 \mathrm{~s}$ 以内で連続 した場合，最後の值を用いる。また吸気の開始点・終了点 におけるサーミスタと呼吸ピックアップベルトの時間差を 算出し，その差が吸気の開始点・終了点ともに $300 \mathrm{~ms}$ 以 内であれば体動がないとみなして呼吸ピックアップベルト の值を，300-1000 ms の間であれば体動があったとみなし てサーミスタの值を用いて RSA 振幅を算出する。それら より外れていた場合，データに信頼性がないとして，RSA 振幅の算出を行わない。その後, $0.15 \mathrm{~Hz}$ 以下の長い呼吸 のデータを除去し, 前 25 回の RSA 振幅の平均值を算出す る。実験環境は図 7 に示すとおりで，得られた RSA の振 幅值は UDP(User Datagram Protocol)を介して CG 生 成用 PC に送信され，CG はプロジェクタで壁面に投影す る。実験プロトコルは図 8 の通りである。セッション 2,5 では，体動として 1 呼吸の間に体幹を前後に 2 回動かすと いう動作を課した。セッション 4-6では，2 章と同じ 2 桁 の暗算を $3 \mathrm{~s} に 1$ 回の速さで行い, 手元のキーボードでの 回答を行った。また，被験者に安静時には投影された $\mathrm{CG}$ を見るよう指示した。

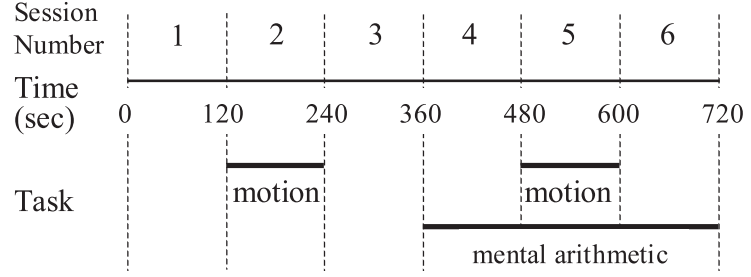

Fig. 8. Time table of the experiment for the realtime RSA extraction with interactive CG

(a)

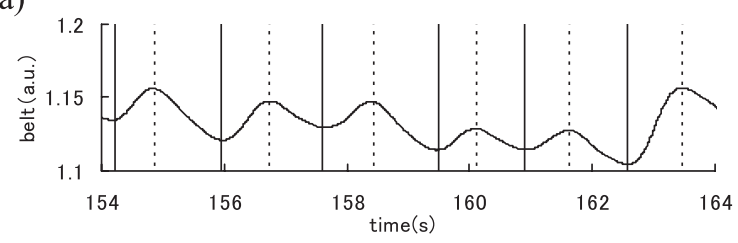

(b)

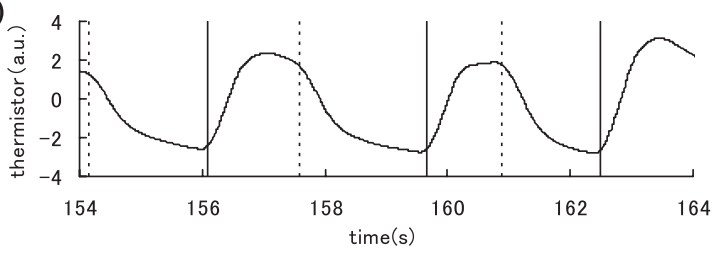

Fig. 9. Waveforms of the (a)respiration belt, and (b)thermistor under the condition of body motion. Solid lines indicate the start points of inspiration and dotted lines indicate the end points of inspiration.

〈3・2〉 CG の生成アルゴリズムＣGには growth モ デル(17) を用い，RSA 振幅の值を $0 \mathrm{~ms}$ から $100 \mathrm{~ms}$ の間 で色，形状，動きのマッピングに用いた。具体的なアルゴ リズムについて，以下にまとめる。色に関しては，0 ms か ら $100 \mathrm{~ms}$ HSI 表色系において色相が $0^{\circ}$ (赤) から $255^{\circ}$ (青紫) の間にマッピングを行い, RGBに変換して用いた。 フラクタルの深さは, growth 描画における再帰関数呼び出 しの深さに相当しており， $0 \mathrm{~ms}$ から $100 \mathrm{~ms}$ を 10 から 0 の整数に換算した值を使用した。また，動きの大きさには， RSA 振幅值の 2 次関数を使用し, growth における枝の角 度の変化量が, RSA 振幅值が低いほど大きくなるようにし た。これらのアルゴリズムによって，副交感神経活動が低 いほど, 赤く, フラクタルの深さが深く, 複雑な形状で動 きが大きいグラフィックスを生成した。

〈3・3〉実験結果 一例の結果について，体動を課した 時刻におけるサーミスタと呼吸ピックアップベルトの呼吸 曲線を図 9 に, 実験全体での RSA の振幅について提案手 法での抽出結果と呼吸ピックアップベルト, サーミスタ単 独の結果とを並べたものを図 10(a) に示す。困 9 の実線と 破線はそれぞれのセンサで同定した吸気の開始点・終了点 を示している。図 9(a) の呼吸ピックアップベルトの波形か ら，1呼吸の間に体幹を前後に 2 回動かす動作による波形 変化を呼吸として抽出してしまっている様子が見て取れる。 
(a)

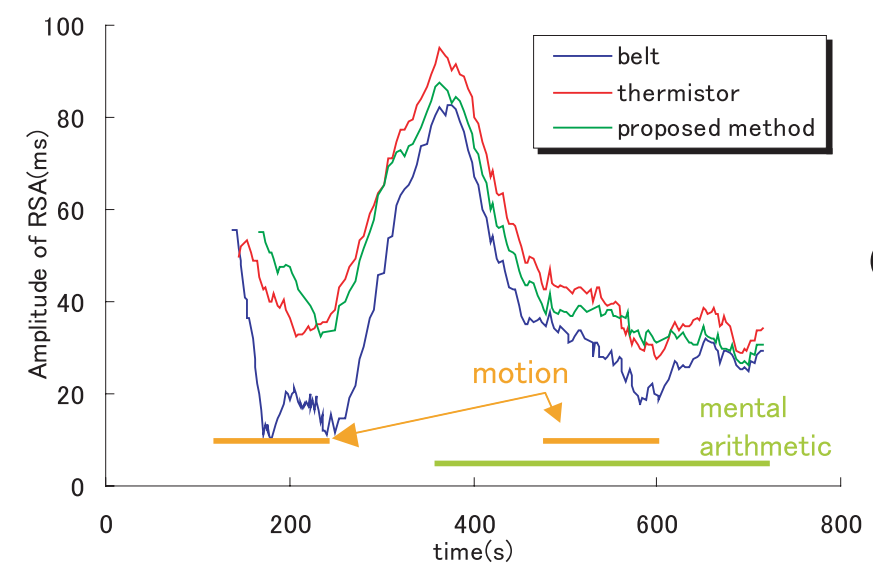

(b)

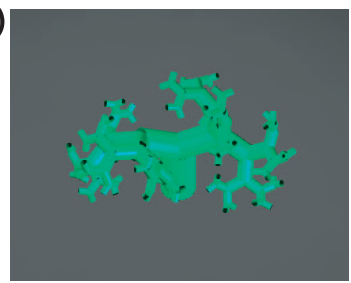

(d)

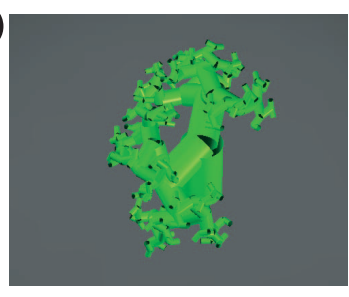

(c)

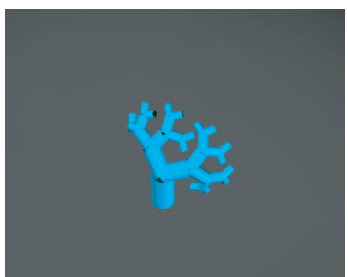

(e)

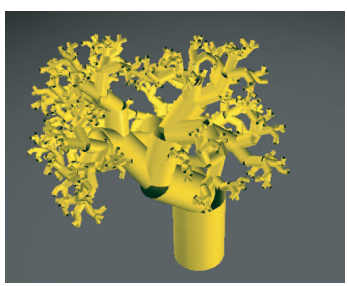

Fig. 10. Result of the experiment for real-time RSA extraction with interactive CG. (a) the amplitude of RSA by belt, thermistor, and the proposed method. (b)200 s, (c)300 s, (d)550 s, and (e)700 s snapshots of CG that reflect the amplitude of RSA.

図 10(a) から，体動のあるセッション 2,5 において，呼吸 ピックアップベルトでは RSA の振幅を低く算出してしまっ ているが，提案手法では呼吸ピックアップベルトとサーミ スタの併用によって正確な RSA 振幅が抽出できているこ とがわかる。ここで，七ッション $2,3,5,6$ における CGの 画像を図 10(b)-(e) に示す。提案手法による RSA 振幅を送 信した結果，タスクに応じてリアルタイムで CG が反応し て動いている様子が見て取れる。

$\langle 3 \cdot 4\rangle$ 考 察 実験の結果，提案した信号処理手 法によって体動を含む条件下であってもリアルタイムでの RSA 振幅の評価が可能であるということがわかった。これ までにも周波数解析，時間周波数解析を用いて RSA を抽 出し, 自律神経活動を評価する研究は, 研究発表 ${ }^{(18)}, \mathrm{NC}$ 工作を模したタスク ${ }^{(19)}$ ，車輛運転 ${ }^{(20)}$ ，船の操縦 ${ }^{(21)}$ ，自転 車運動 (22) などの様々な場面について行われている。提案 した手法は複数の呼吸情報を取得することで RSA 振幅の 抽出精度を向上させ，リアルタイムでのデータ解析を可能 としているため，これらの場面を含めた実生活環境下での 最適なインターフェイスの構築において有用と考えられる。

また，インタラクティブアートの分野においてはこれまで は随意的な運動とのインタラクションが主だったが(23) (24), 本研究では不随意な自律神経活動指標を用いて CG を動か すシステムを構築した。本研究の CG は自律神経活動に対 してポジティブフィードバックを形成するように作成され ており，そのようなインタラクティブアートと自律神経活 動との間に閉ループを目指した試みは独創的といえる。困 10(a)のセッション 3 において, RSA の振幅が高くなって いるのは，動きが小さくなっていく CGを見ていることに よるポジティブフィードバックの影響が含まれている可能 性があるが，今回の実験条件ではポジティブフィードバック の効果の大きさを正確に評価することはできないため，そ の点に関しては今後の課題である。

\section{4. 結論・展望}

$\langle\mathbf{4} \cdot \mathbf{1}\rangle$ 結 論 本研究では, 動きのある状況下で の RSA 振幅のリアルタイム抽出手法について, 安静時と 体動を含む作業下で RSA 振幅の抽出実験を行い, 安静時 にはサーミスタより呼吸ピックアップベルトの方が高精度 に呼吸を計測できること，体動が大きい時にはサーミスタ を用いることが有効であること, 瞬時 RRI の補間法として は IHR 法よりも Berger 法を用いた方が RSA 振幅の抽出 精度が高いことがわかった。さらに，これらの結果を用い ることで，副交感神経活動をリアルタイムに推定して外部 $\mathrm{PC}$ に送信し，CGがリアルタイムに反応するシステムを 構築することができた。

$\langle 4 \cdot 2\rangle$ 展望本研究で提案したシステムは, リ アルタイムに自律神経活動を推定して外部環境の制御を可 能とするものである。今後, RSA 振幅の抽出手法に関して は, さらに誤差要因の検討を行い, センサや信号処理手法 の改良を図ることで，実生活環境下での使用に耐え得るシ ステムを構築していく。また，応用面に関しては，インタ ラクティブアート以外にも作業支援, リラクゼーションと いった目的に応用する事ができる。以下に，それぞれの目 的についての展望を述べる。

まず，インタラクティブアートにおいては，これまで随意 運動が主であったが，本研究では不随意な自律神経活動指 標を用いるシステムを提案した。今回は映像それ自体のポ ジティブフィードバック効果は検証しなかったが, 今後さら に情動に大きな影響を与えるような CGを作成し，フィー ドバック効果の検証実験を行う。また，作業支援目的にお いては，RSA 振幅の值に応じて休憩を入れる，あるいは作 業速度や手法を変えるような制御を行うことが望まれる。 リラクゼーション目的では今回用いたような映像に加えて, 空調，照明などの外的環境を変化させることで，自律神経 
活動を反映した周囲の環境の最適化を目指す。

謝 辞

本研究の一部は科学技術振興機構 CREST ならびに文部 省科学研究費萌芽研究 (課題番号 18650024) の支援を受け ている。

(平成 19 年 2 月 13 日受付，平成 19 年 6 月 18 日再受付)

\section{文献}

（1） R. M. Berne and M. N. Levy (監訳 坂東武彦, 小山省三) : 「生 理学（第 3 版）」，西村書店 (1996)

(2) J. A. Taylor, T. D. Williams, D. R. Seals, and K. P. Davy "Low-frequency arterial pressure fluctuations do not reflect sympathetic outflow: gender and age differences", Am. J. Physiol. Heart Circ. Physiol., Vol.274, pp.1194-1201 (1998)

(3) J. Hayano, S. Mukai, M. Sakakibara, A. Okada, K. Takata, and T. Fujinami: "Effect of respiratory interval on vagal modulation of heart rate", Am. J. Physiol., Vol.267, pp.H33-H40 (1994)

(4) P. G. Katona and F. Jih: "Respiratory sinus arrhythmia: noninvasive measure of parasympathetic cardiac control", $J$. Appl. Physiol., Vol.39, pp.801-805 (1975)

(5) B. Pomeranz, R. J. B. Macaulay, M. A. Caudill, I. Kutz, D. Adam, D. Gordon, K. M. Kilborn, A. C. Barger, D. C. Shannon, R. J. Cohen, and H. Benson: "Assesment of autonomic function in humans by heart rate spectral analysis", Am. J. Physiol., Vol.248, pp.H151-H153 (1985)

(6) Task Force of the European Society of Cardiology and the North American Society of Pacing and Electrophysiology: "Heart rate variability: standards of measurement, physiological interpretation, and clinical use", Circulation, Vol.93, pp.1043-1065 (1996)

(7) K. Hirayanagi, K. Iwasaki, S. Kanda, and K. Yajima: "An experimental study on the measurement and assessment of mental workload (MWL)", The Japanese journal of ergonomics, Vol.32, No.5, pp.251-259 (1996) (in Japanese)

平柳 要・岩崎賢一・神田省吾・谷島一嘉:「メンタルワークロー ド $(\mathrm{MWL})$ の測定・評価法に関する実験的検討」，人間工学， 32,5 , pp.251-259 (1996)

(8) K. Kotani, I. Hidaka, Y. Yamamoto, and S. Ozono: "Analysis of respiratory sinus arrhythmia with respect to respiratory phase", Meth. Inf. Med., Vol.39, pp.153-156 (2000)

(9) K. Kotani, K. Furukawa, and K. Takamasu: "Accurate extraction of respiratory sinus arrhythmia with respect to respiratory information", Trans. of the Japanese society for medical and biological enginnering, Vol.41, No.3, pp.197-204 (2003) (in Japanese)

小谷 潔・古川健太・高増 潔: 「呼吸情報に着目した高精度な呼吸 性洞性不整脈の抽出法」, 生体医工学, 41-3, pp.197-204 (2003)

(10) K. Kotani, M. Tachibana, and K. Takamasu: "Respiratory phase domain analysis of heart rate variability can estimate cardiac vagal activity accurately during a mental arithmetic task," Methods of Information in Medicine, Vol.46, pp.376385 (2007)

(11) K. Kotani, T. Saito, M. Tachibana, and K. Takamasu: "Workload control using the real-time extraction of respiratory sinus arrhythmia", Trans. of the Japanese society for medical and biological enginnering, Vol.43, No.2 pp.252-260 (2005) (in Japanese) 小谷 潔・斉藤 毅・立花 誠・高増 潔:「リアルタイム呼吸性 洞性不整脈抽出法を用いた作業負荷の制御」，生体医工学，43-2, pp.252-260 (2005)

(12) Shari R. Waldstein, Willem J. Kop, Louis A. Schmidt, Amy J. Haufler, David S. Krantz, and Nathan A. Fox: "Frontal electrocortical and cardiovascular reactivity during happiness and anger", Biological Psychology, Vol.55, pp.3-23 (2000)

(13) Thomas W. Frazier, Milton E. Strauss, and Stuart R. Steinhauer: "Respiratory sinus arrhythmia as an index of emotional response in young adults", Psychophysiology, Vol.41, pp.75-83 (2004)

（14）水田博久.八名和夫：「心拍ゆらぎの $1 / \mathrm{f}$ スペクトル推定」, $\mathrm{BME}$
8-10, pp.13-16 (1994)

(15) K. Han, J. H. Nagel, and N. Schneiderman: "A continuous representation of heart rate", Proc. Ann. Int. Conf. IEEE/ EMBS No.14, pp.785-786 (1992)

(16) R. D. Berger, S. Akselrod, D. Gordon, R. J. Cohen: : "An efficient algorithm for spectral analysys of heart rate variability", IEEE TBME, Vol.33, pp.900-904 (1986)

17) Y. Kawaguchi: "A morphological study of the form of nature", Proc. of SIGGRAPH'82(Boston,July 1982), Computer Graphics, Vol.16-3, pp.223-232 (1982)

18) H. Takatsu, M. Munakata, O. Ozeki, K. Yokoyama, Y. Watanabe, and K. Takata: "An evaluation of the quantitative relationship between the subjective stress value and heart rate variability, IEEJ trans EIS, Vol.120, No.1, pp.104-110 (2000-1) (in Japanese)

高津浩彰・宗像光男 - 小関 修・横山清子 - 渡辺與作・高田和之： 「心拍変動による精神的ストレスの評価についての検討」電学論 C, 120, 1, pp.104-110 (2000-1)

19) K. Hirasawa, T. Sakaguchi, and M. Ohsuga: "Analysis of operating behaviours using autonomic indices -second report-", BPES2001, pp.261-264 (2001) (in Japanese) 平澤宏祐・坂口貴司・大須賀美恵子:「自律神経系指標を主に用いた 作業行動解析-第二報-」，第 16 回生体生理工学シンポジウム論文 集, pp.261-264 (2001)

(20) K. Yokoyama, N. Omi, Y. Morimoto, Y. Mizuno, and K. Takata: "Evaluation of mental and physical workload while driving using wavelet transform of heart rate time series", IEEJ transactions on electronics, infromation and systems, Vol.22, No.1, pp.36-41 (2002-1) (in Japanese) 横山清子・大見直史 $\cdot$ 森本陽子・水野康文・高田和之 : 「拍変動時 系列のウェーブレット変換による車輛運転時生体負担評価」電学論 C, 122, 1, pp.36-41 (2002-1)

21) K. Murai, Y. Hayashi, and Y. Yano: "Navigator's stress level for ship handling by actual ships and ship's bridge simulators", BPES2001, pp.253-256 (2001) (in Japanese) 村井康二・林 祐司・矢野吉治：「実操船とシミュレータ操船に押 ける操船者の緊張度」, 第 16 回生体生理工学シンポジウム論文集, pp.253-256 (2001)

(22) S. Kato, T. Kiryu, T. Moriya, and Y. Mizuno: "Effect of power assist on physical activities during cycling exercise", IEICE technical report. ME and bio cybernetics, Vol.102, pp.37-40 (2002) (in Japanese)

加藤慎也・木竜 徹 ·守屋貴於 - 水野博文 : 「自転車運動時生体機 能の変化におけるパワーアシストの影響」，信学技研報，Vol.82, pp.37-40 (2002)

23) Y. Kawaguchi: "Gemotion dance" ACM SIGGRAPH 2006 Art Gallery SIGGRAPH '06. ACM Press, NY, p.113 (2006)

24) M. W. Krueger: "Artificial Reality II", Addison-Wesley Publishing Company (1991)

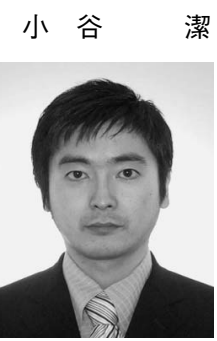

(非会員) 2003 年東京大学大学院工学系研究科 精密機械工学専攻博士課程修了。同大学院情報理 工学系研究科特任助手を経て, 現在，同大学院新 領域創成科学研究科講師。非線形動力学, 統計物 理学, 生体信号処理, ヒューマンインターフェイ スの研究に従事。日本生体医工学会，精密工学会 等の会員。工学博士。

飯 田 文 明 (非会員) 2007 年東京大学工学部システム創成

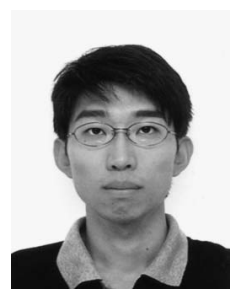
学科卒業。現在，同大学院工学系研究科精密機械 工学専攻修士課程に在学中。 
赤 川 智 洋 (非会員) 2004 年公立はこだて未来大学システ

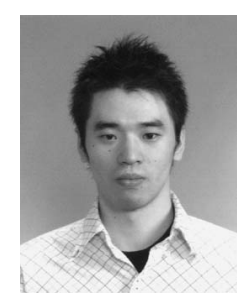
ム情報科学部卒業。2006 年同大学院システム情 報科学研究科博士課程 (前期) 修了。現在, 東京 大学大学院学際情報学府修士課程在学中。インタ ラクティブコンピュータグラフィックスの研究に 従事。

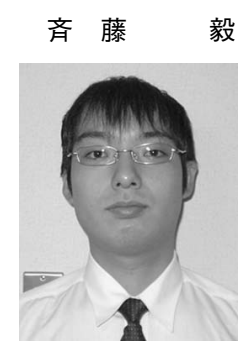

(非会員) 2005 年東京大学工学部システム創成 学科卒業。2007 年同大学院工学系研究科精密機 械工学専攻修士課程修了。現在, (株) ファナック に勤務。

\section{神 保 泰彦}

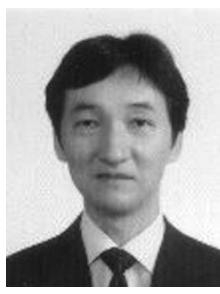

(正員) 1988 年東京大学大学院工学系研究科電 子工学専門課程修了, 工学博士。同年, NTT 基 礎研究所研究員。1992-1993 年, フランス CNRS 客員研究員。2003 年, 東京大学大学院工学系研 究科精密機械工学専攻助教授, 2006 年より同新 領域創成科学研究科人間環境学専攻教授。主とし て, 神経工学の研究に従事。電子情報通信学会, 日本神経科学学会, 日本生体医工学会, IEEE 等
河 口 洋一郎 (非会員) 東京大学大学院/情報学環教授, CG

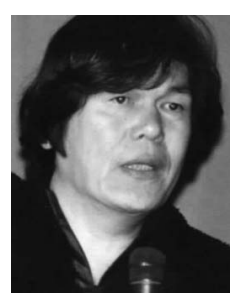
アーティスト 1952 年鹿児島県種子島生。1976 年 九州芸術工科大学 (現九州大学) 卒, 1978 年東 京教育大学大学院（現筑波大学大学院）修了。筑 波大学芸術学系助教授を経て, 1998 年より東京 大学大学院工学系研究科・人工物工学センター 教授。2000 年より東京大学大学院情報学環教授。 1975 年から CG 制作・研究を手がけ, 米国 ACMSIGGRAPH 国際学会で「グロースモデル: Growth Model」の自己 増殖する造形論文を発表。生き物のように情感的に凹凸反応する「ジェ モーション：Gemotion」による舞台空間のパフォーミング・アーツ も国際的に手がける。

高 増 潔 (正員) 1982 年 東京大学大学院工学系研究科

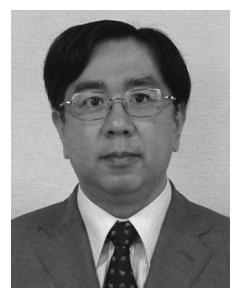
精密機械工学専攻博士課程修了。同大学工学部助 手, 東京電機大学工学部講師, 助教授を経て, 現 在, 東京大学大学院工学系研究科教授。精密計測, 三次元計測, ナノメートル計測, 光計測, 計測標 準, 計測の不確かさの研究に従事。精密工学会, 計測自動制御学会, euspen の会員。工学博士。

の会員。 